\title{
RECOVERY OF SOME VALUABLE ELEMENTS FROM HIGHLY FERRUGINOUS SHALE, UM BOGMA FORMATION, WADI UM HAMED, SOUTH WESTERN SINAI, EGYPT.
}

\author{
Radwan, H. A. ; Faheim, A. A. ${ }^{\dagger}$; El-Sheikh, E. M. ; Abd El-Wahab, Z. H. ${ }^{\dagger}$ and \\ Gado, M. A." \\ * Geology of isotopes, Nuclear Materials Authority, Cairo, Egypt. \\ ${ }^{\dagger}$ Chemistry Department, Faculty of Science, Al-Azhar University (Girls), Youssif Abbas St., \\ Nasr-City, Cairo, Egypt, P.O. Box 11754.
}

\begin{abstract}
The present work describes a study of the acidic pug leaching technique for $\mathrm{U}$ - extraction in addition to some associated valuable metals from a collected technological sample of ferruginous shale from Wadi Um Hamed of Um Bogma Formation at Abu Thor locality of southwestern Sinai, Egypt. A representative sample of the ore material was found to assay 900 , 700 and $400 \mathrm{ppm}$ of REEs, $\mathrm{U}$ and $\mathrm{Cu}$, respectively in addition to some major and minor oxides. Numerous steps were perform upon the studied sample to process parametric studies like sulfuric acid concentration (50-150 kg/ton), curing time $(0.5-5.0 \mathrm{~h})$ and curing temperature (50$150^{\circ} \mathrm{C}$ ) in order to assess the best one giving the optimum conditions. Under the optimal conditions $\left(150 \mathrm{~kg} /\right.$ ton sulfuric acid for $4.0 \mathrm{~h}$ at $\left.150^{\circ} \mathrm{C}\right)$, the first step involved Fe-removal as hydroxide from the pregnant leaching solution using $\mathrm{pH}$ adjustment method followed by $\mathrm{U}$ recovery through sorption / desorption and precipitation steps with the help of Amberlite IRA400-Cl (strongly basic anion exchange resin) via column method. In the third step, REEsrecovery from $\mathrm{U}$ - free effluent was investigated using oxalic acid precipitation process while $\mathrm{Cu}$ - recovery by precipitation as hydroxide with ammonia solution was tack place.
\end{abstract}

\section{Keywords}

Uranium; Wadi Um Hamed; Southwestern Sinai; Egypt; Pug leaching efficiency; Kinetic modeling.

\section{INTRODUCTION}

Uranium is a naturally occurring element found in a wide variety of rocks, soils and water everywhere in modest concentrations. Uranium belongs to the actinide series of the periodic table and has the chemical symbol U, atomic weight $238.03 \mathrm{~g} / \mathrm{mol}$, atomic number 92 and melting point $1132.2^{\circ} \mathrm{C}$. $\mathrm{U}$ is a mixture of three main radioactive isotopes ${ }^{234} \mathrm{U},{ }^{235} \mathrm{U}$ and ${ }^{238} \mathrm{U}$ with approximately abundances $0.005,0.72$ and $99.27 \%$, respectively. Additionally, $U$ is a multivalent element, can exist naturally in several oxidation states, from +2 to +6 (the most important one are +4 and +6 oxidation states having different solubility).

It never occurs in the native form in nature, but it combined with various other elements forming uranium-bearing minerals in two oxidation states. The tetravalent oxidation states such as: pitchblende $\left(\mathrm{U}_{3} \mathrm{O}_{8}\right)$, uraninite $\left(\mathrm{UO}_{2}\right)$, uranothorite $\left[(\mathrm{U}, \mathrm{Th})\left[\mathrm{SiO}_{4}\right]\right.$ and coffinite $\left[\mathrm{U}\left(\mathrm{SiO}_{4}\right)_{1-\mathrm{x}}(\mathrm{OH})_{4 \mathrm{x}}\right]$; and the hexavalent oxidation states such as: carnotite $\left[\mathrm{K}_{2}\left(\mathrm{UO}_{2}\right)_{2}\left(\mathrm{VO}_{4}\right)_{2} \cdot 3 \mathrm{H}_{2} \mathrm{O}\right]$, autunite $\left[\mathrm{Ca}\left(\mathrm{UO}_{2}\right)_{2}\left(\mathrm{PO}_{4}\right)_{2} \cdot 10 \mathrm{H}_{2} \mathrm{O}\right]$, uranophane $\left[\mathrm{Ca}\left(\mathrm{UO}_{2}\right)_{2}\left[\mathrm{Si}_{2} \mathrm{O}_{7}\right] \cdot 6 \mathrm{H}_{2} \mathrm{O}\right]$ and torbernite $\left[\mathrm{Cu}\left(\mathrm{UO}_{2}\right)_{2}\left(\mathrm{PO}_{4}\right)_{2} \cdot 8 \mathrm{H}_{2} \mathrm{O}\right][1,2]$. The general technology for $\mathrm{U}$ - recovery from its different sources involves sequent steps summarizing as ore milling, crushing and reduction to a suitable average size followed 
by leaching with an appropriate lixiviant to give a final pregnant leach liquor known as uranium mother liquor from which subsequent recovery and precipitation steps tack place forming a yellow cake.

Finally, this yellow cake produces a remarkable final product for market through the calcination process $[3,4]$. Moreover, pyrometallurgy and hydrometallurgy are the commonly methods used to metals recovery in mineral processing. Several factors must be considered, to decide whether to apply or not, and the most important one emphasis on the environment and economy. In hydrometallurgy, leaching is the more important step in which the dissolution of ore minerals was processed through lixiviant. The selection of the correct lixiviant based on mineral composition, capital investment, ore grade and other [5]. Additionally, several procedure patterns are applied for leaching process and generally, they grouped into in situ leach, dump leach, heap leach, vat leach and agglomerated fines heap leach [6].

The present study aimed at evaluating the pug leaching technique using sulfuric acid for the separation and recovery of the uranium in addition to some associated valuable metals from the ore material obtained as ferruginous shale from Wadi Um Hamed of Um Bogma Formation at Abu Thor locality of southwestern Sinai, Egypt. The effect of sulfuric acid concentration, time and temperature on the leaching efficiency of metals was investigated.

\section{EXPERIMENTAL DESIGN}

\subsection{Reagents and Ore Material}

The used technological ore material under work was obtained as ferruginous shale from Wadi Um Hamed of Um Bogma Formation at Abu Thor locality of southwestern Sinai, Egypt. Amberlite IRA-400 in chloride form abbreviated as Amb 400-Cl (Dow Chemical Company) is a commercial strong anion exchange resin. Hydrochloric, nitric, sulfuric and oxalic acids were analytical grade and were used as supplied.

\subsection{Instruments and Equipment Used}

All samples and reagents used in this work were weighed using a precise balance of type Schimadzu AY 220, with an accuracy of \pm 0.01 and stability of sensitivity of $10^{-4} \mathrm{~g}$. A digital $\mathrm{pH}$ meter (Patterson Scientific) was used for measuring the $\mathrm{pH}$ values of the different solutions until a $\mathrm{pH}$ range of 14.00 with an accuracy \pm 0.1 . Before any measurements, the $\mathrm{pH}$ meter scale was calibrated using a standard buffer solution at ambient room temperature. An atomic absorption spectrometer model, GBC-932AA (Australia) fitted with the corresponding lamp was used for $\mathrm{Cu}$-analyses. UV-Visible spectrophotometer model Shimadzu UV-160A, England with $5 \mathrm{~cm}^{3}$ quartz cell and a path length of $1 \mathrm{~cm}$ was used for REEs -analyses covering a wavelength range of 200$1100 \mathrm{~nm}$.

The environmental scanning electron microscope coupled with an energy dispersive $\mathrm{X}$ ray analyzer, Philips XL 30 type was used to define the elemental composition of the investigated ore. The PXRD was performed at ambient temperature on a Philips X-ray diffractometer, model PW 223/20 with a nickel filtered $\mathrm{Cu}$ anode material radiation with an intensity weighted average of $1.54184 \AA$ as the radiation sources. 
The applied voltage of the instrument and the operating current are $40 \mathrm{kV}$ and $20 \mathrm{~mA}$, respectively, with a scan speed of $2 \mathrm{~s}$ per 0.03 sample rotation. The diffraction patterns were recorded at room temperature in the range $2 \theta=10-80^{\circ}$ with a continuous scan mode.

\subsection{Initial Processing of Ore Martial}

The ore material under study is a ferruginous shale obtained from Wadi Um Hamed of Um Bogma Formation at Abu Thor locality of southwestern Sinai, Egypt. At first, the ore was cleaned and air-dried to reduce the moisture content and to facilitate the other successive treatments. The ore was run throughout the crushing, grinding followed by sieving with standard sieves to produce particles size of $-200 \mathrm{~mm}$ mesh size to make the ore more susceptible to high metals extraction then placed in a desiccator until use during the experiment.

\subsection{Identification of the Ore Martial Composition}

The ore martial composition was identified utilizing the mineralogical and chemical analysis. The mineralogical analysis of the studied sample was examined through X-ray diffraction (XRD) and energy dispersive X-ray analysis (EDXA) equipments whereas, the chemical analysis was proceed for its constituents as major oxides besides a tenor of economic elements values after a suitable digestion. This is performed by an alkaline digestion of the studied sample in fused $\mathrm{NaOH}$ solution to determine $\mathrm{SiO}_{2}$ and $\mathrm{Al}_{2} \mathrm{O}_{3}$ while the acidic digestion of the studied sample in acidic mixture of $\mathrm{HF}(48 \%)$, concentrated $\mathrm{H}_{2} \mathrm{SO}_{4}$ and concentrated $\mathrm{HNO}_{3}$ acids allow to determine the total iron, $\mathrm{MgO}, \mathrm{CaO}, \mathrm{TiO}_{2}, \mathrm{P}_{2} \mathrm{O}_{5}, \mathrm{MnO}, \mathrm{Na}_{2} \mathrm{O}$, and $\mathrm{K}_{2} \mathrm{O}$ utilizing the appropriate techniques [7]. Moreover, U-content was analyzed via oxidimetric titration against ammonium metavanadate in the presence of a diphenylamine sulfonate indicator [8]. Total REEs concentration was determined with arsenazo III spectrophotometry method at a wavelength, $\lambda 654 \mathrm{~nm}$ [9]. Cu-content was determined using an atomic absorption spectrometer at $\lambda$ a wavelength, $222.60 \mathrm{~nm}$. From the obtained results, the potential composition of the working ore material is tabulated in table 1.

Table (1): The chemical composition of the working technological ore sample under study.

\begin{tabular}{|c|c|c|c|c|c|}
\hline Major component & Wt.\% & Minor component & Wt.\% & Trace element & ppm \\
\hline $\mathrm{SiO}_{2}$ & 40.11 & $\mathrm{~K}_{2} \mathrm{O}$ & 1.80 & REEs & 900 \\
\hline $\mathrm{Fe}_{2} \mathrm{O}_{3}$ & 27.50 & $\mathrm{CaO}$ & 1.30 & $\mathrm{U}$ & 700 \\
\hline $\mathrm{Al}_{2} \mathrm{O}_{3}$ & 16.09 & $\mathrm{TiO}_{2}$ & 1.14 & $\mathrm{Cu}$ & 400 \\
\hline & & $\mathrm{Na}_{2} \mathrm{O}$ & 1.06 & & \\
\hline & & $\mathrm{P}_{2} \mathrm{O}_{5}$ & 0.41 & & \\
\hline \multicolumn{7}{|l|}{$\mathrm{MgO}$} & 0.40 & & \\
\hline$*$ LOI $=9.00$ & & $\mathrm{l}$ & \\
\hline
\end{tabular}

*LOI represents total loss in ignition.

\subsection{Estimate the Weight Loss on Ignition}

The weight loss on ignition (LOI) is a simple inexpensive gravimetric method used for estimation the water content as well as the organic matter based on sequential heating of the sample in a muffle furnace followed by measuring the weight loss at each specific 
temperature. Typically, a known weighed of dry sample $-200 \mathrm{~mm}$ mesh size was introduced into previously weighed clean porcelain crucible and heated in a furnace at $105^{\circ} \mathrm{C}$ until a constant weight.

This allows determining water content using the weight of dry sample before and after heating at $105^{\circ} \mathrm{C}$. The procedure was conducted for the same sample and a continuous heating in a muffle furnace to about 200 into $900^{\circ} \mathrm{C}$ allow to determine the LOI due to the organic matter using the weight of dry sample before and after ignition at each specific temperature through the following equation [10]:

$$
\text { LOI }(\%)=\frac{\text { Mass loss of sample at a specific temperature }}{\text { Mass of the original sample }} \times 100
$$

\subsection{Ore Sample Dissolution Using Pug Leaching Method}

This method includes impregnating a specified weight of the dry ore suitable to a laboratory scale with in aqueous solutions of sulfuric acid as leaching agent and curing the formed pasts at different periods of time and temperatures. Typically, $10.0 \mathrm{~g}$ of coarsely ground dry ore was mixed with a suitable volume of sulfuric acid of a definite concentration in a porcelain crucible then heated in a laboratory muffle furnace under the effect of the different working parameters. At the end of a certain period and after cooling, filter and carefully wash the crucible content several times with distilled water to remove all of the residual liquor that was absorbed by the leached ash. Both the filtrate and wash solution were collected together in a volumetric flask to produce the final pregnant leach solution (PLS) and the total volume of PLS solution was recorded to be a $25 \mathrm{~mL}$. This PLS solution is a solution containing the dissolved valuable metals and can be used in recovery of such metals [11].

To study the effects of different working parameters; the input sulfuric acid concentration, curing time and curing temperatures on the working sample, various leaching experiments were performed in which, the factor of interest was changed while the other leaching factors were fixed at appropriate values.

The effect of the input sulfuric acid concentration was study between 50 and $150 \mathrm{~kg} /$ ton while the other working parameters as curing time and curing temperature were fixed at $3 \mathrm{hr}$ and $120^{\circ} \mathrm{C}$, respectively. The effect of the curing time was studied at different periods ranging from 0.5 to $5.0 \mathrm{hr}$ at optimized input sulfuric acid concentration while the temperature was fixed at $120^{\circ} \mathrm{C}$. The effect of the curing temperature was studied from $50^{\circ} \mathrm{C}$ up to $150^{\circ} \mathrm{C}$, under the previously determined optimum conditions for sulfuric acid addition and curing time. Table 2, summarizes all the different working parameters.

Table (2): The proper leaching conditions and their effect in leaching experiments.

\begin{tabular}{|c|c|c|}
\hline Working parameters & Working value & Leaching efficiency (\%) \\
\hline Acid concentration $(\mathrm{kg} /$ ton $)$ & $50,75,100,150^{*}$ & $66.75,71.21,78.11,80.11$ \\
\hline Leaching time $(\mathrm{h})$ & $0.5,1,2,3,4^{*}, 5$ & $54.53,60.15,65.44,80.11,94.80,95.66$ \\
\hline Curing temperature $\left({ }^{\circ} \mathrm{C}\right)$ & $50,75,100,120,150^{*}$ & $65.83,82.24,90.3,94.80,97.61$ \\
\hline
\end{tabular}

*Parameters values were kept constant for subsequent experiment. 


\subsection{Sequent Recovery of Valuable Metals}

First, $1 \mathrm{~kg}$ of the working dry ore material under study has been subjected to acid pug leaching procedure under the previously determined optimum conditions then left to cool. Second, the cooling roasted ore sample was leached with distilled water for $2 \mathrm{~h}$ at room temperature resulted in two liters of PLS solution carrying the dissolved valuable elements. The obtained results of analysis of this PLS solution revealed the chemical composition as given in table 3 .

Table (3): Chemical components of pregnant leach liquor with their leaching efficiencies.

\begin{tabular}{|c|c|c|c|c|c|}
\hline Element & Si & Fe & REEs & Cu & U \\
\hline Content (g/L) & 19.00 & 13.48 & 4.455 & 1.98 & 341.00 \\
\hline Leaching efficiencies (\%) & 95.00 & 98.00 & 99.00 & 99.00 & 97.61 \\
\hline
\end{tabular}

\subsubsection{Iron removal process}

To remove the iron from PLS solution, the $\mathrm{pH}$ adjustment method was applied [12]. In this method, the pH value of the PLS was increased to 3.5 by using $20 \% \mathrm{NaOH}$ solution. As a result, a precipitate of iron component took place. This precipitate was filtered, washed and dried while the filtrate was adjusted to $\mathrm{pH} 1.8$ for the second step in which the uranium recovery proceeds.

\subsubsection{Uranium recovery process}

Amberlite IRA400 anion exchange resin in chloride form; Amb400-Cl was used as a sorbent for U-recovery from PLS solution free from Fe. The specifications and characteristic properties of $\mathrm{Amb} 400-\mathrm{Cl}$ were given in table 4. The extraction process involves three main subsequent stages namely loading, elution and precipitation.

Table (4): Physicochemical properties of the ion exchanger Amberlite IRA400 Cl resin.

\begin{tabular}{|c|c|}
\hline Parameter & Remarks \\
\hline Physical form & Pale yellow translucent spherical beads \\
\hline Polymer matrix & Styrene divinylbenzene copolymer \\
\hline Functional group & quaternary ammonium group; $-\mathrm{N}_{\left(\mathrm{CH}_{3}\right)_{3}{ }^{+}}$ \\
\hline Ionic form (as shipped) & $\mathrm{Chloride} ; \mathrm{Cl}^{-}$ \\
\hline Ion exchange capacity & $\geq 1.40 \mathrm{meq} / \mathrm{ml}\left(\mathrm{Cl}^{-}\right.$form $)$ \\
\hline Effective size & $0.3-0.9 \mathrm{~mm}$ \\
\hline Operating temperature & $80^{\circ} \mathrm{C}($ maximum $)$ \\
\hline pH range & $0-14$ \\
\hline
\end{tabular}

\subsubsection{Loading process of uranium}

At first, a portion of Amb400-Cl was washed thoroughly with distillated water to remove the adhering dirt until the supernatant became clear and colorless then soaked in distillated water for $24 \mathrm{hr}$ before use. After that an accurate $7.38 \mathrm{ml}$ wet settled resin poured into a Pyrex column (internal diameter: $0.5 \mathrm{~cm}$ and depth: $9.4 \mathrm{~cm}$ ) provided with a glass wool plug at the top and outlet to prevent the fine grained from transfer and support the ore bed. The resulting bed was ca. $10 \mathrm{~cm}$ high. After that, PLS solution with $\mathrm{pH}$ value of 1.8 was passed through the column downward with flow rate of $1.2 \mathrm{~mL} /$ 
min and regularly, $100 \mathrm{~mL}$ samples were collected from the outlet of the column through such continuous mode adsorption study for checking U- concentration. This operation was continued until attaining the point of saturation at which U-concentration at the outlet reached its initial concentration [13].

\subsubsection{Elution process of uranium}

Subsequently, after the ion exchange was completed, the resin column was first washed with distilled water followed by passing an eluent solution composed of $1 \mathrm{~N} \mathrm{NaCl}$ acidified with $0.25 \mathrm{M}$ sulfuric acid [14] using a flow rate of $1.4 \mathrm{~mL} / \mathrm{min}$ and collecting the obtained elute every $10 \mathrm{~mL}$ for uranium analyses.

\subsubsection{Precipitation process of uranium}

Finally, uranium from the collected eluate was precipitated at a $\mathrm{pH}$ of about 6.5 using $30 \% \mathrm{NH}_{4} \mathrm{OH}$ solution [15] then filter, wash and dried at $110^{\circ} \mathrm{C}$ to give a crude yellow cake. Consequently, refining of this crude cake was proceeded by dissolving in a solution of $\mathrm{NH}_{4} \mathrm{CO}_{3} / \mathrm{NH}_{4} \mathrm{HCO}_{3}$ in $1: 3$ ratio under stirring for $1 / 2 \mathrm{~h}$ at room temperature followed by adjustment of the $\mathrm{pH}$ value of 5.5 where uranium precipitation is take place. Afterward, it is filtered, washed and dried at $110^{\circ} \mathrm{C}$. Then it is calcined at $850^{\circ} \mathrm{C}$.

\subsubsection{Rare earth elements recovery process}

After uranium removing, an effective recovery of rare earth elements $\left(\mathrm{REE}_{\mathrm{s}}\right)$ was obtained by oxalic acid precipitation process [16] in which the effluent solution was adjusted to $\mathrm{pH} 1.0$ followed by addition to $30 \%$ oxalic acid resulted in a precipitation of $\mathrm{REE}_{\mathrm{s}}$ as oxalates. The precipitated REE oxalates were filtered, followed by addition of concentrated hydrochloric acid to dissolve it and again, add $10 \%$ oxalic acid to obtain pure precipitate of the $\mathrm{REE}_{\mathrm{s}}$ as oxalates. The filtered pure precipitate was washed and dried at $80^{\circ} \mathrm{C}$ followed by ignition at $850^{\circ} \mathrm{C}$ for $2 \mathrm{~h}$ to give the corresponding REEoxides while, the filtrate and washing liquid were collected together to be used in copper recovery.

\subsubsection{Copper recovery process}

The obtained filtrate from the above step was treated with ammonia solution (28\%) to adjust the $\mathrm{pH}$ value to 5.5 resulted in a precipitation of copper as hydroxide. The copper hydroxide filterate was washed with distilled water, left to dry then subjected to calcination process resulting in copper oxides. The filtrate was used in the final next step.

\subsubsection{Silica recovery process}

After removing the valuable elements as $\mathrm{Fe}, \mathrm{U}, \mathrm{REE}_{\mathrm{s}}$ in addition to $\mathrm{Cu}$, it is important to obtain silica gel as by-product. This was carried out by adjusting the $\mathrm{pH}$ value of the filtrate to 8.5 via ammonium hydroxide solution (28\%) resulting in a precipitation of silica. The precipitate was filtered, washed with distilled water, left to dry then subjected to ignition process at $850^{\circ} \mathrm{C}$ for $1 \mathrm{~h}$ resulted in silica oxide. 


\section{RESULTS AND DISCUSSION}

\subsection{Characterization of Ore Material under Study}

Qualitative investigation of the ferruginous shale from Wadi Um Hamed of Um Bogma Formation at Abu Thor locality of southwestern Sinai, Egypt, was proceeded via XRD and SEM-EDX equipment. The mineralogical characterization using XRD, figure 1, was fairly interpreted using standard diffraction mineral patterns revealing the main phases as clay minerals, quartz, hematite, gypsum and microcline. Moreover, presence of $\mathrm{Si}, \mathrm{Fe}, \mathrm{Al}, \mathrm{K}, \mathrm{V}$ and $\mathrm{U}$ contents were identified via SEM-EDX as clear from figure 2. It is worthy to mention here that the studied raw material shows no specific REEs, $\mathrm{Cu}$, $\mathrm{V}$ or $\mathrm{U}$ bearing minerals. This is probably due to the ability of hematite to incorporate a significant proportion of such elements and others into its mineral structure depending on its high sorption capacity in addition to some environmental parameters as temperature, pressure, coexisting fluids as well as the partition coefficients of these elements, all having a rule [17]. This phenomenon was observed elsewhere [18].

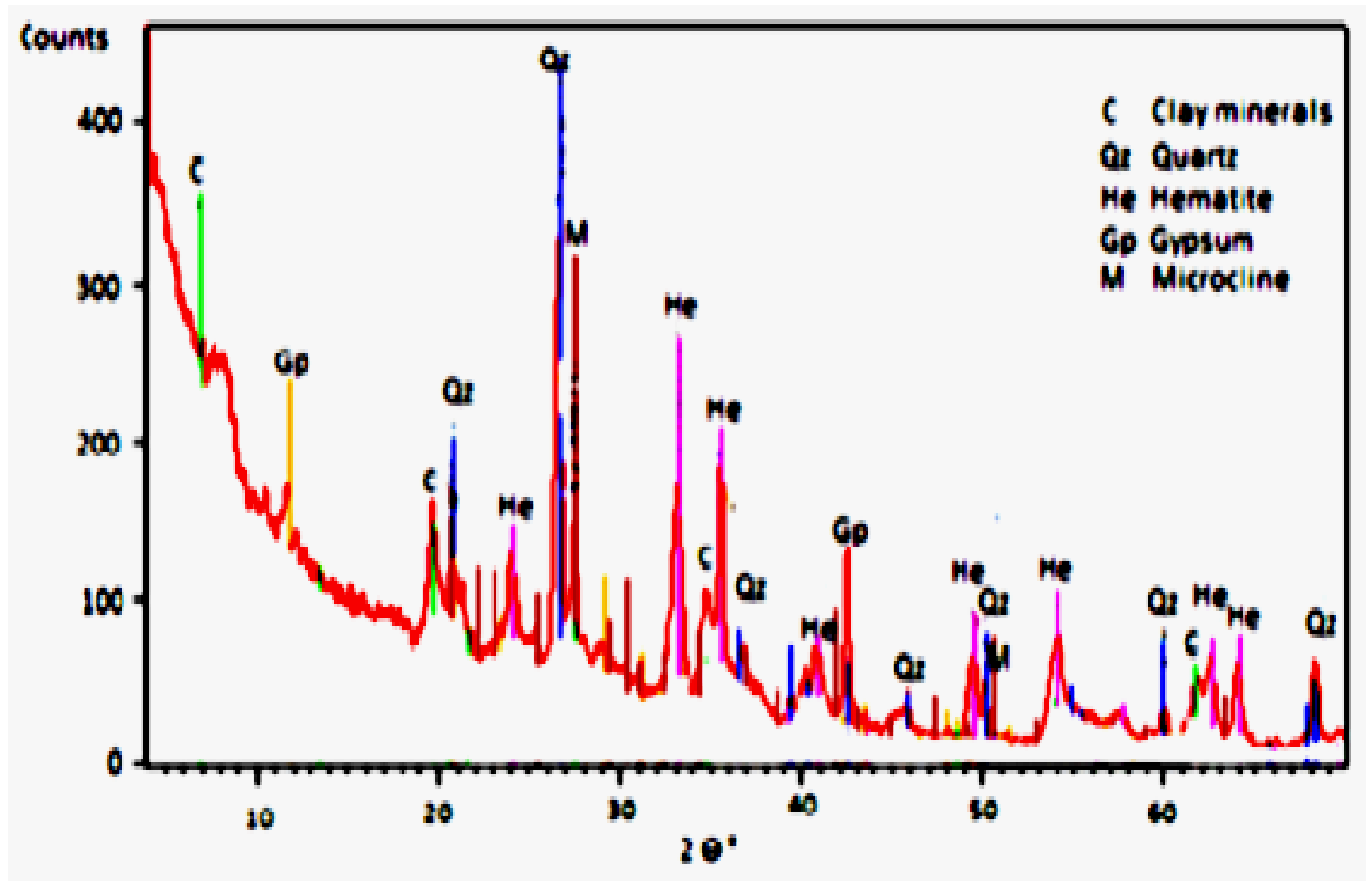

Fig. 1: X-Ray diffraction patterns of ore material under study.

On the other hand, the quantitative mineralogical composition of the ore material, table 1, indicates presence of a high level of $\mathrm{SiO}_{2}, \mathrm{Fe}_{2} \mathrm{O}_{3}$ and $\mathrm{Al}_{2} \mathrm{O}_{3}$ as major oxides attaining 40.11, 27.50 and $16.09 \%$, respectively. This is besides $\mathrm{K}_{2} \mathrm{O}, \mathrm{CaO}, \mathrm{TiO}_{2}, \mathrm{Na}_{2} \mathrm{O}, \mathrm{P}_{2} \mathrm{O}_{5}$ and $\mathrm{MgO}$ as minor oxides as well as trace elements of REEs, $\mathrm{U}$ and $\mathrm{Cu}$. It is clear to know, the high silicon content as $\mathrm{SiO}_{2}$ due to presence of kaolinite $\left(\mathrm{Al}_{2} \mathrm{Si}_{2} \mathrm{O}_{5}(\mathrm{OH})_{4}\right)$ and microcline $\left(\mathrm{KAlSi}_{3} \mathrm{O}_{8}\right)$ in addition to quartz $\left(\mathrm{SiO}_{2}\right)$ in the phase structure of the ore material [19]. 

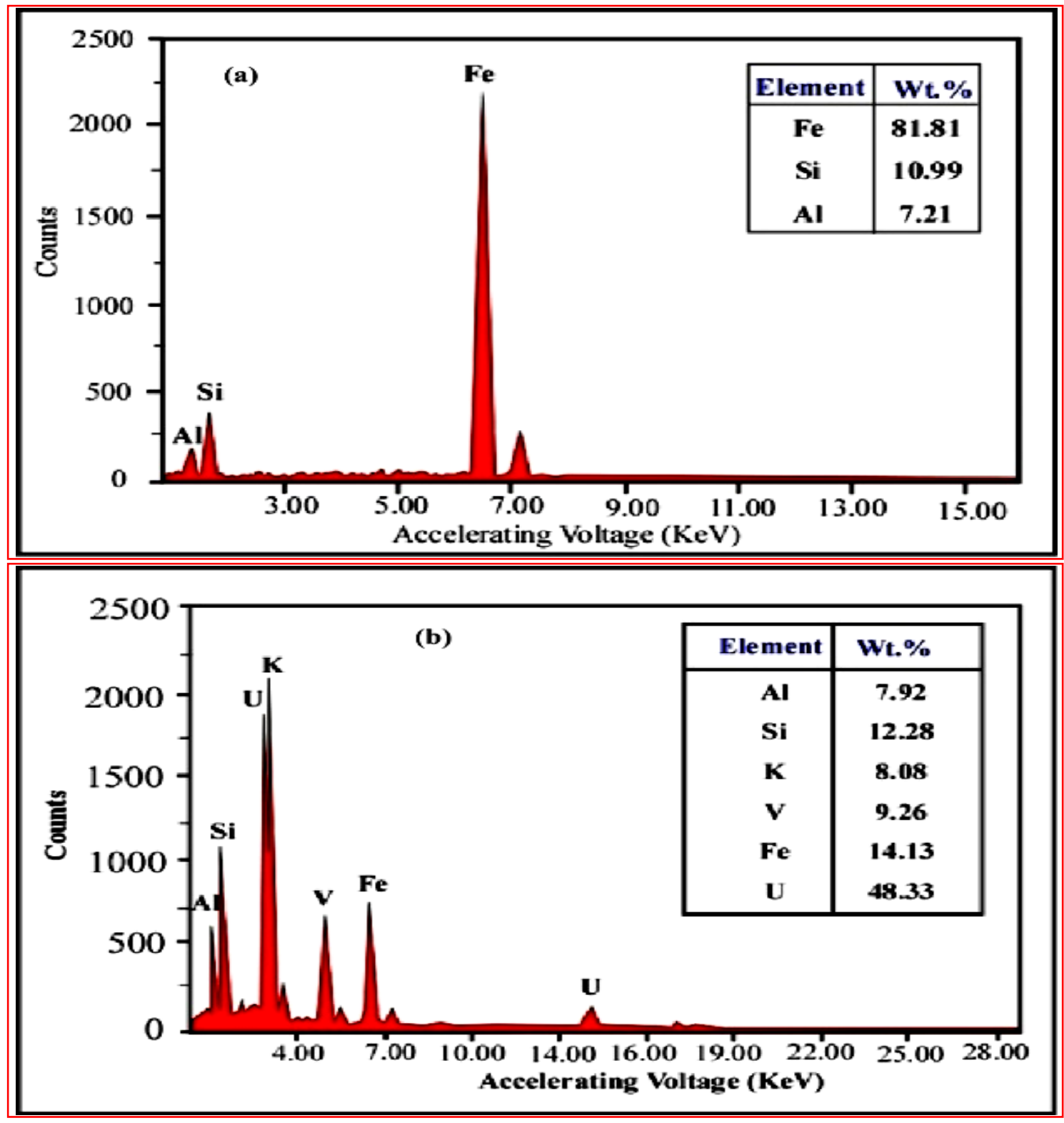

Fig. 2: EDX analysis of (a) bulk and (b) sieved samples of ore material under study.

\subsection{Ore Dissolution and Optimization of the Working Parameters}

The dissolution procedure aimed to dissolve part / all of the components of the studied material and can take place in either an acidic or an alkaline medium. Dissolution by acid was preferred than alkali where, acids are able to leach more efficiently for coarser grinds and consequently, they offer more rapid dissolution kinetics. Acid leaching with sulfuric acid is a convenient method due to its low cost and its efficiency for different types of uranium ores [20, 21]. The dissolution of $U$ - bearing ores is influenced by a number of chemical process factors including leaching time, temperature, acid concentration, liquid - solid ratio, $\mathrm{pH}$ of medium and presence of oxidizing agent besides a number of ore properties as ore nature, ore grade, particle size and ore composition [22, 23] 
In the present work, acidic medium using the sulfuric acid was applied through pug leaching technique. The input sulfuric acid concentration, curing time and curing temperatures were studied. Additionally, leaching efficiency can be calculated using the following equation [24].

$$
\text { Leaching efficiency }(\%)=\frac{\text { Metal content in the leach liquor }}{\text { Original metal content in the ore }} \times 100
$$

\subsubsection{Effect of the added amount of sulfuric acid}

The dissolution behavior of the ore sample as a function of sulfuric acid concentration was studied in the range of $50-150 \mathrm{~kg} /$ ton for a curing time $3 \mathrm{hr}$ and $120^{\circ} \mathrm{C}$ curing temperature. The results were tabulated in table 2 and shown in figure $4 \mathrm{a}$. It can be seen from figure 3 that leaching process strongly depended on acid concentration where, increasing the acid concentration from 50 to $150 \mathrm{~kg} / \mathrm{ton}$, led to an increment in uranium extraction from 66.75 to $80.11 \%$ in $3 \mathrm{hr}$ and $120^{\circ} \mathrm{C}$. These results indicate that, the higher acid concentration enhances the diffusion of sulfuric acid from bulk solution to the surface and then increases reaction rate at the interface [25]. In addition, increasing acid concentration led to an increase in $\mathrm{H}^{+}$activity and according to the Le chatelier's principle, the reaction shift to the right direction, i.e. increasing the amount of leaching [26]. Therefore, the acid concentration $(150 \mathrm{~kg} / \mathrm{ton})$ was selected for the consequent tests.

\subsubsection{Effect of curing time}

To monitor the dissolution of the ore sample under study, wide periods of the curing time ranged from 0.5 to $5.0 \mathrm{~h}$ with fixing other leaching conditions at $150 \mathrm{~kg} / \mathrm{ton}$ acid concentration and $120^{\circ} \mathrm{C}$ were applied. The results were tabulated in table 2 and shown in figure $4 \mathrm{~b}$. It is expected that, longer contact time between the leaching agent and the solid material under study enhancement the dissolution of the particles of solid material components resulted in more release of its components into the solution. In contracts, the shortest leaching time causes the leaching reaction to be less likely to occur where, the sample particles still being in the dense conditions [27]. In our experiment, the leaching efficiency increased from $54.53 \%$ to $94.80 \%$ through $4 \mathrm{~h}$. while further increasing of curing time up to $5.0 \mathrm{~h}$ did not affect significantly on the leaching efficiencies. Therefore, the time of $4 \mathrm{hr}$ was applied in the study because of save energy.

\subsubsection{Effect of curing temperature}

The effect of temperature on the leaching efficiencies was studied from 50 to $150^{\circ} \mathrm{C}$ while fixing the other experimental conditions at $150 \mathrm{~g} / \mathrm{L}$ acid concentration and time of $4 \mathrm{~h}$. The obtained data are presented graphically in figure $4 \mathrm{c}$ and listed in table 2 . It can be seen that there are rapid dissolution occurred within the three first temperatures tested leading to increases in leaching efficiencies from 65.83 to $95.23 \%$, a small increase at the two final temperatures tested and the ore was largely dissolved at $150^{\circ} \mathrm{C}$ with maximum leaching efficiencies up to $97.61 \%$. The increase in leaching efficiencies due to the increase in the thermal movement of molecules and the reaction rate as a result to facilitate the migration of leaching agent into the inner layers of the ore as well as to transport the dissolved metals from inside the particle to the leachate [28]. 

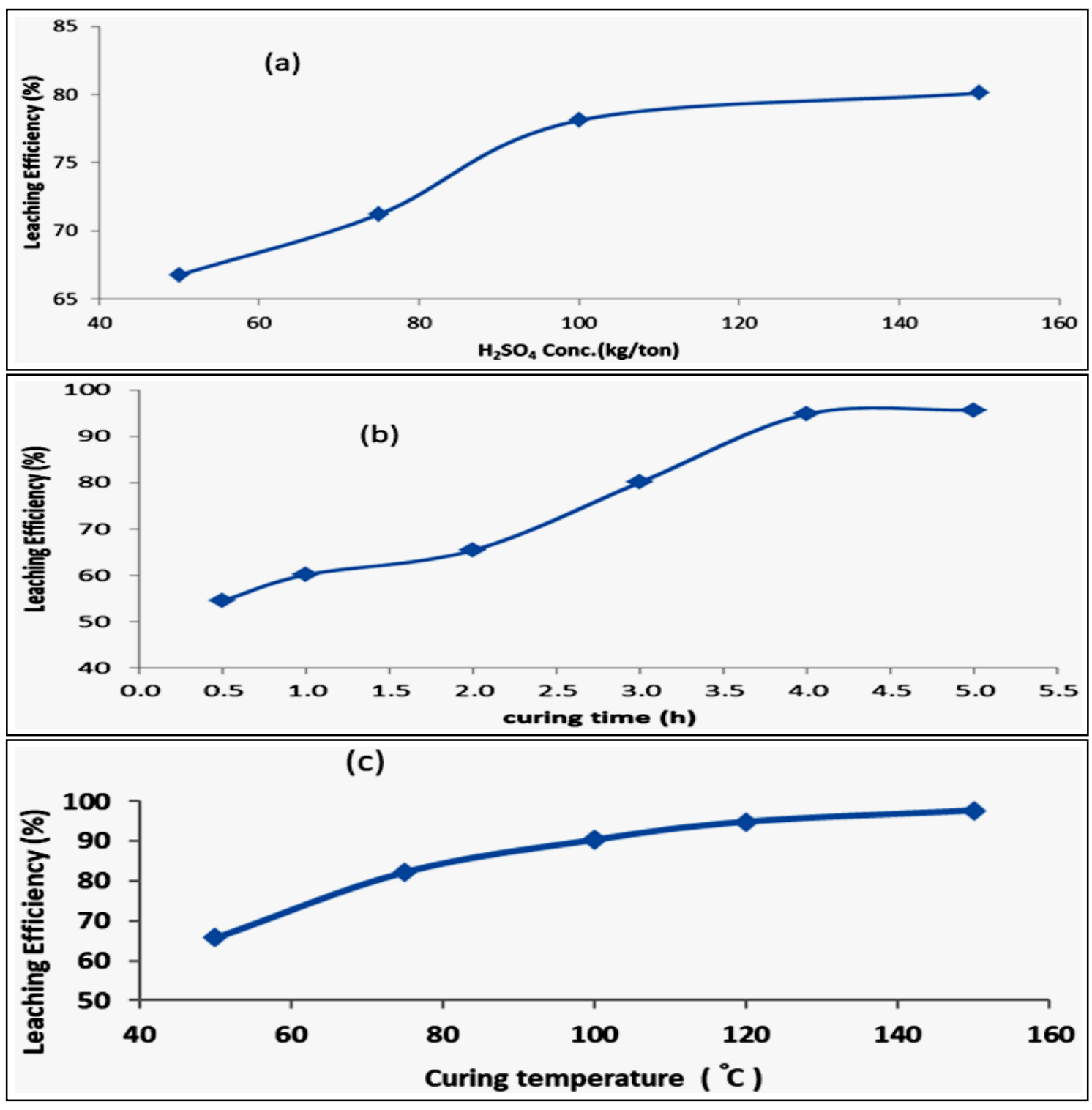

Fig. 3: Effect of the different working parameters upon pug leaching method:

(a) Effect of $\mathrm{H}_{2} \mathrm{SO}_{4}$ acid concentration (Operation conditions: $3 \mathrm{~h}$ and $120^{\circ} \mathrm{C}$ ).

(b) Effect of curing time (Operation conditions: $150 \mathrm{~kg} /$ ton $\mathrm{H}_{2} \mathrm{SO}_{4}$ and $120^{\circ} \mathrm{C}$ ).

(c) Effect of curing temperature (Operation conditions: $150 \mathrm{~kg} / \mathrm{ton} \mathrm{H}_{2} \mathrm{SO}_{4}$ and $4 \mathrm{~h}$ ).

\subsection{Valuable Metals Recovery}

Generally, the chemical precipitation method was applied to separate and recovery the valuable metals after suitable treatment. Chemical precipitation is a simple easily treatment method where, it almost only needs chemical precipitant agent to react with the metal ions and change them into insoluble solid particles have the ability to be separated from the solution by sedimentation or filtration process. Alkaline agents can be used to increase the medium $\mathrm{pH}$ and so, decrease the solubility of metal ions resulted in formation of a precipitate [29]. 


\subsubsection{Iron recovery using $\mathrm{pH}$ adjustment method}

For eliminating the Fe-interference with U-extraction process, PLS solution was treated at first to remove iron component prior to U recovery. Treatment of PLS solution with sodium hydroxide solution resulted in an increase in its $\mathrm{pH}$ value up to 3.5 and precipitation of Fe content as hydroxide [30]. The obtained precipitate was subject to filtration and washing followed by drying at $110^{\circ} \mathrm{C}$ then upon calcination at $850^{\circ} \mathrm{C}$, it converts to $\mathrm{Fe}_{2} \mathrm{O}_{3}$.

$$
\mathrm{Fe}_{2}\left(\mathrm{SO}_{4}\right)_{3}+6 \mathrm{NaOH} \longrightarrow 3 \mathrm{Na}_{2} \mathrm{SO}_{4}+2 \mathrm{Fe}(\mathrm{OH})_{3(\mathrm{~s})}
$$

The obtained $\mathrm{Fe}_{2} \mathrm{O}_{3}$ is confirmed by means of EDX analysis (figure 4) to have a purity of $99.16 \%$ with associated impurities of $0.84 \% \mathrm{~S}$.

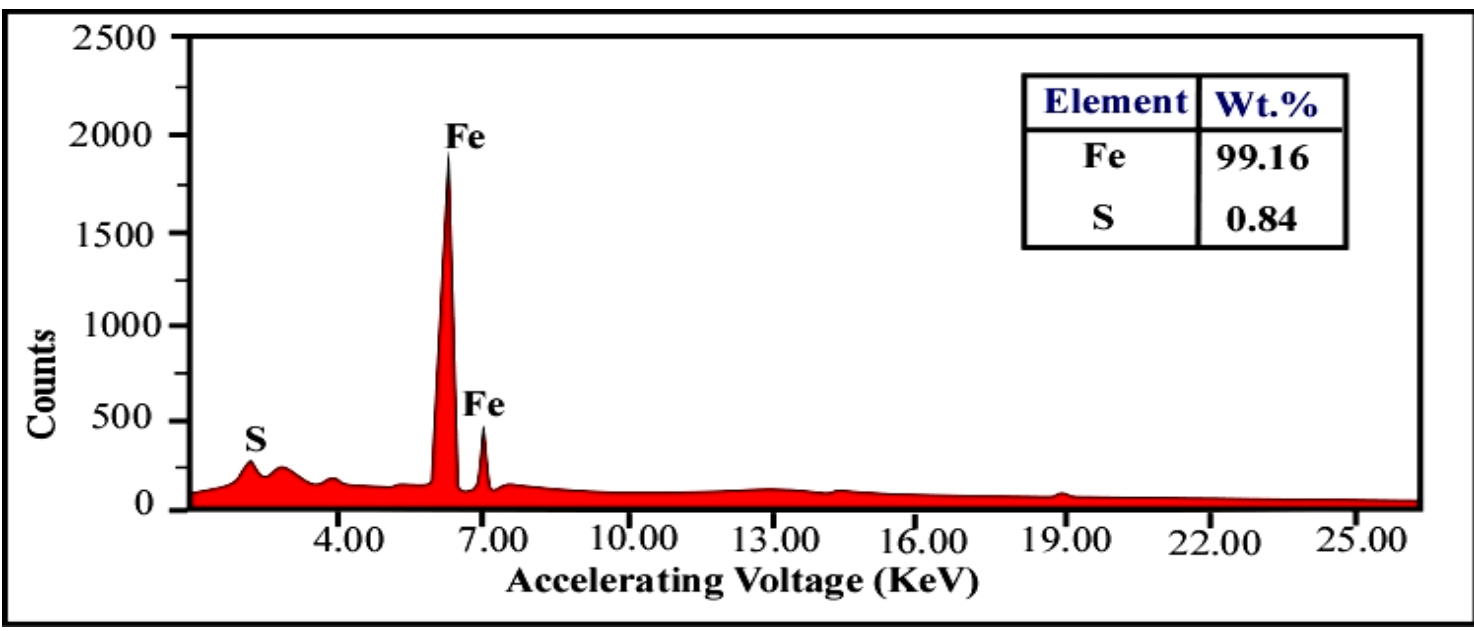

Fig. 4: EDX analysis of Fe product extracted from ore material under study.

\subsubsection{Uranium recovery using Amberlite IRA400}

Various techniques have been employed for recovery and removal of uranium from aqueous solution as coagulation, coprecipitation, reduction, nanofiltration, ultrafiltration, liquid membrane, high performance liquid chromatography, gas chromatography, adsorption, bioremediation, solid phase extraction, liquid-liquid extraction, electrodeposition and ion exchange. Among these methods, ion exchange method due to its selectivity, less sludge volume, metal recovery at low concentrations and ability to regenerate the resin is the most prefered compared to other techniques, moreover, the strong base anion exchange resins are considered to be the most suitable choice for uranium recovery $[31,32]$.

In our experiment, uranium was recovered from PLS solution by using the ion exchanger Amberlite IRA400-Cl resin (Amb400-Cl) represents appearance photograph of Amb400-Cl before and after sorption process. Moreover, figure 5 represents Uuptake by Amberlite IRA 400-Cl resin and the obtained results for uranium analysis from loading experiments were plotted in figure 6, represents the elution profile of loaded uranium Amberlite IRA400 saturated resin column. 


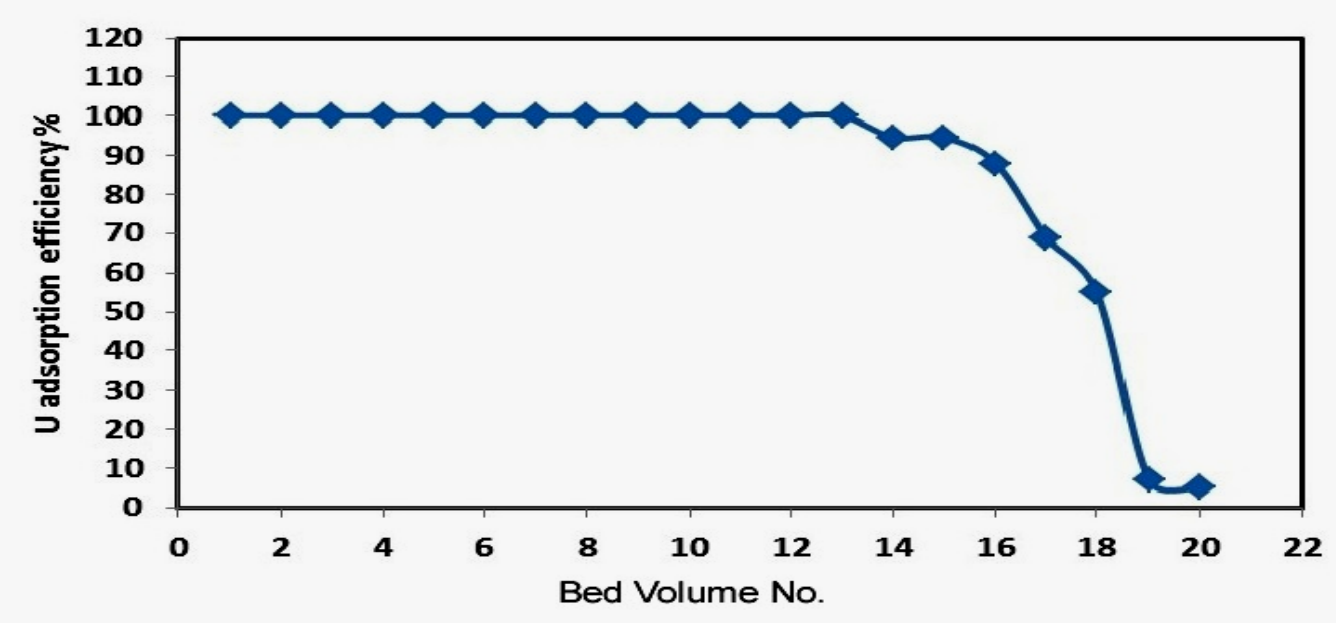

Fig. 5: Uranium uptake by Amberlite IRA 400-Cl resin.

$($ Each aliquot sample volume $=100 \mathrm{~mL})$

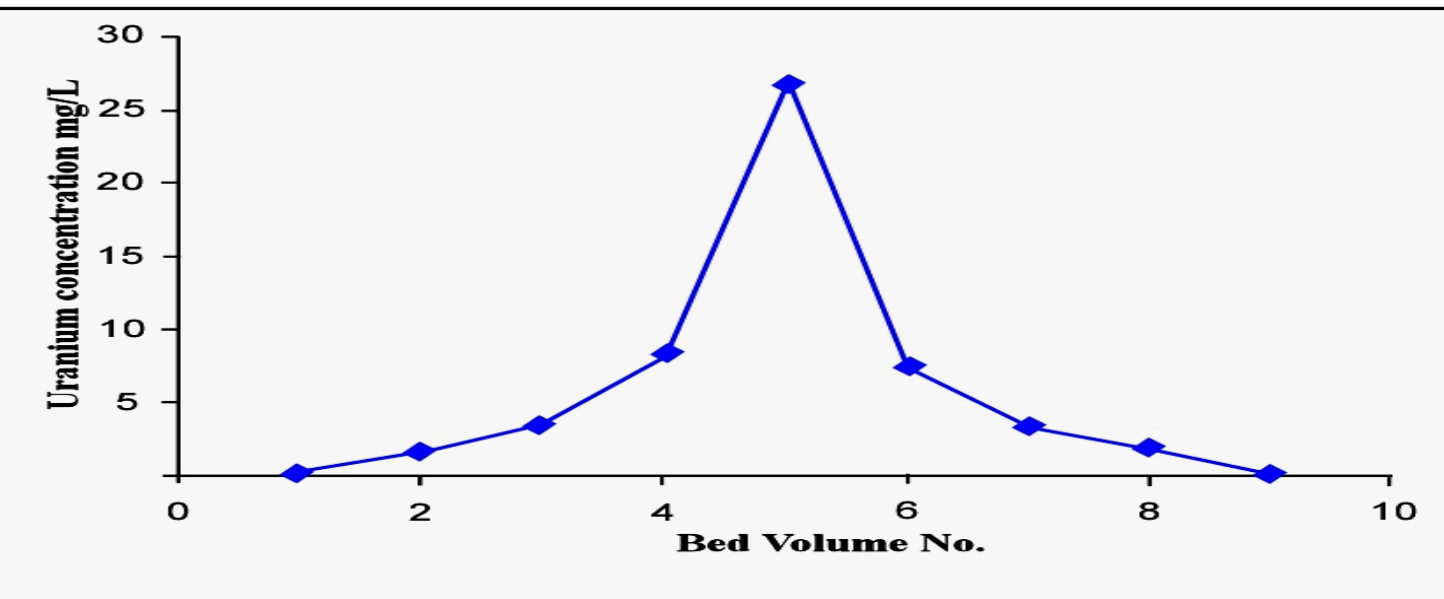

Fig. 6: Elution profile of loaded uranium Amberlite IRA400 saturated resin column $($ Each aliquot sample volume $=10 \mathrm{~mL})$.

The sorption curve, figure 5, reflects that the amount of U-loaded was $0.584 \mathrm{~g}$ with an adsorption efficiency of $85.65 \%$. Furthermore, the elution curve, figure 6 , shows that for the first 5 bed volume, most uranium is eluted from the resin and the elution process was complete after 6-9 bed volume of eluent. Additionally, the total amount of eluted uranium reached was $0.526 \mathrm{~g}$, suggesting an efficiency of elution of about $90.06 \%$.

The percentage of uranium eluted expressed as [33].

$$
\text { Uranium eluted }(\%)=\frac{\text { Amount of uranium eluted }}{\text { Amount of uranium loaded }} \times 100
$$


After that, uranium from the collected elute was used to obtain the final U-product. Typically, U-elute was precipitated followed by filtration, washing and purification as explained in the experimental part. The obtained purified product as ammonium diuranite was subjected to a higher temperature $\approx 800^{\circ} \mathrm{C}$ for calcination process giving $\mathrm{U}_{3} \mathrm{O}_{8}$ [34]. The analysis of $\mathrm{U}_{3} \mathrm{O}_{8}$ product using EDAX (figure 7) shows that $\mathrm{U}$ assay achieving about $98.76 \%$.
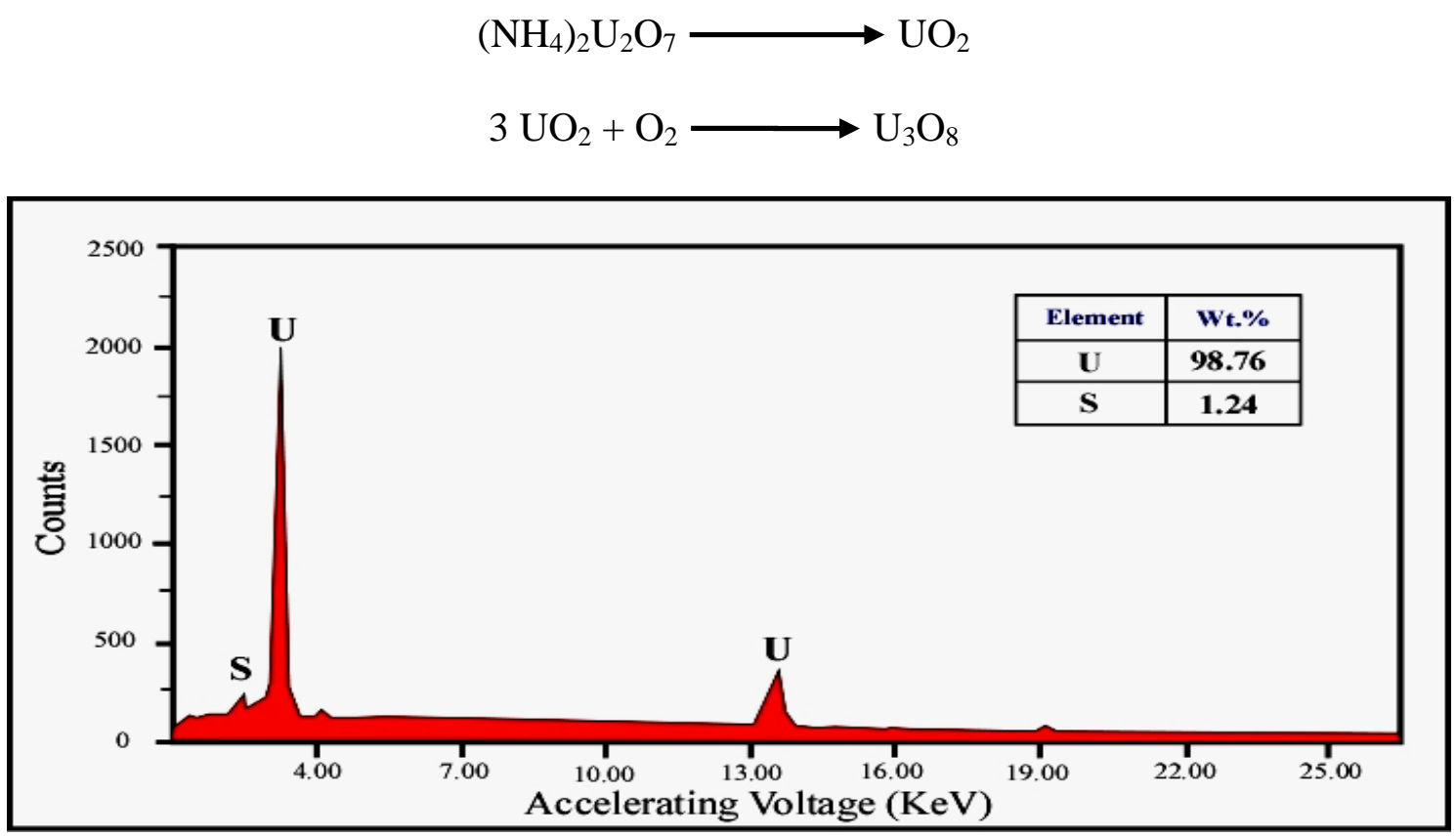

Fig. 7: EDAX analysis of Uranium product.

It is worthy to mention here that, removal of uranium from sulfate media by anion exchange resins due to the ability of uranyl ions to form anionic sulfate complexes as $[35,36]$ :

$$
\begin{gathered}
\mathrm{UO}_{2}{ }^{2+}+\mathrm{SO}_{4}{ }^{2-} \longrightarrow \mathrm{UO}_{2} \mathrm{SO}_{4} \\
\mathrm{UO}_{2}{ }^{2+}+2 \mathrm{SO}_{4}{ }^{2-} \longrightarrow \\
\mathrm{UO}_{2}{ }^{2+}+3 \mathrm{SO}_{4}{ }^{2-} \longrightarrow
\end{gathered}
$$

Furthermore, such uranium sulfate complexes were found to have high affinity for the anionic exchange resins and their interaction with $\mathrm{Amb} 400-\mathrm{Cl}$ resin may be according to:

$$
\begin{aligned}
{\left[\mathrm{UO}_{2}\left(\mathrm{SO}_{4}\right)_{2}\right]^{2-}+2 \mathrm{RCl} } & \longrightarrow \mathrm{R}_{2}\left[\mathrm{UO}_{2}\left(\mathrm{SO}_{4}\right)_{2}\right]+2 \mathrm{Cl}^{-} \\
{\left[\mathrm{UO}_{2}\left(\mathrm{SO}_{4}\right)_{3}\right]^{4-}+2 \mathrm{RCl} } & \longrightarrow \mathrm{R}_{4}\left[\mathrm{UO}_{2}\left(\mathrm{SO}_{4}\right)_{3}\right]+4 \mathrm{Cl}^{-}
\end{aligned}
$$

The structure of Amberlite IRA $400 \mathrm{Cl}$ Resin and a simple representation to its interaction with Uranyl ions was given in figure 8. 

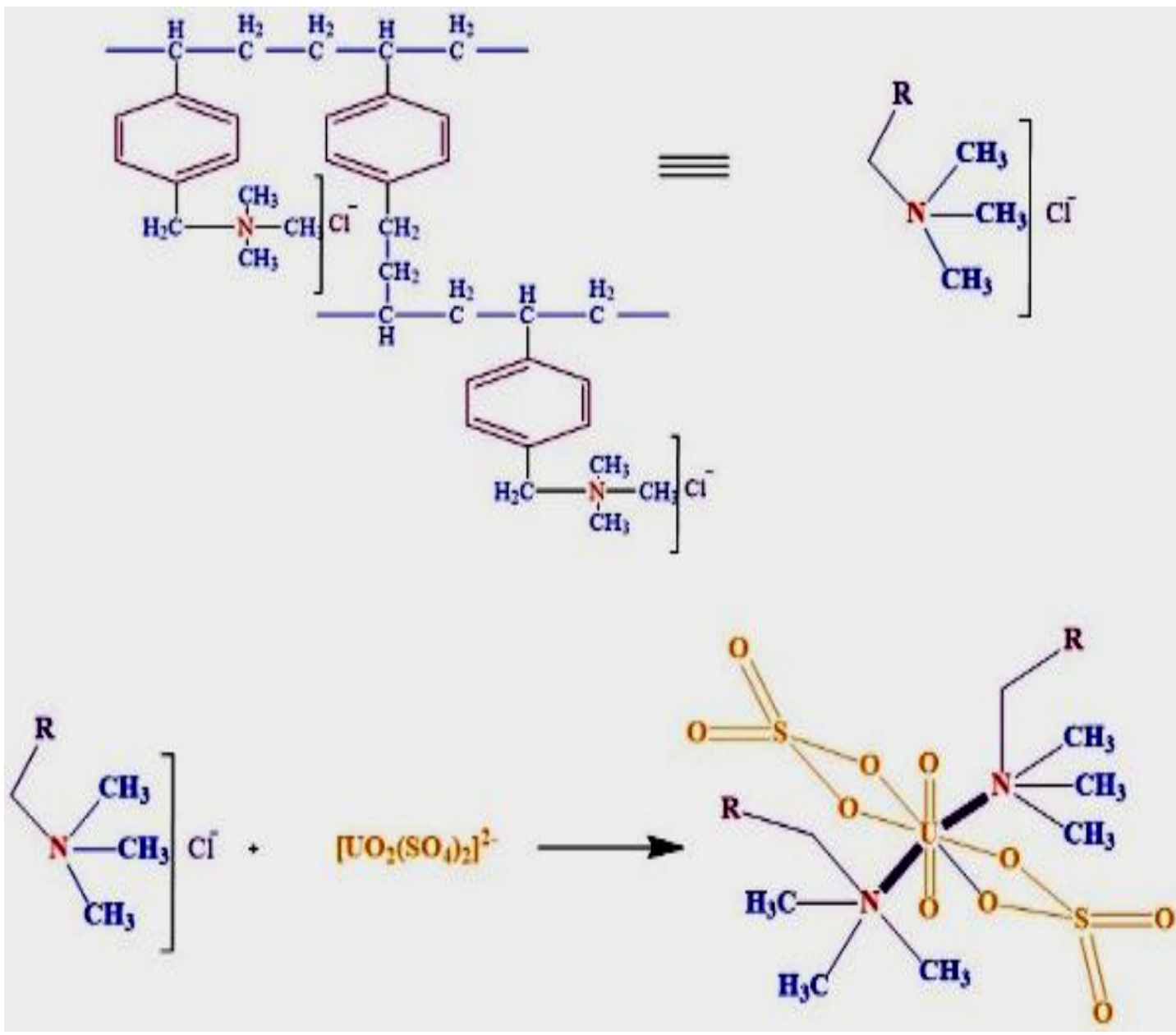

Fig. 8: Structure of Amberlite IRA $400 \mathrm{Cl}$ Resin and a simple representation to its interaction with Uranyl ions.

\subsection{Rare Earth Elements Recovery using Oxalic Acid Precipitation}

There are different methods can be used in recovery process for rare earth elements $\left(\mathrm{REE}_{\mathrm{s}}\right)$ from U-free PLS solution. The oxalic acid precipitation process was applied due to strong affinity of the oxalate ion for $\mathrm{REE}_{\mathrm{s}}$ and the low solubility of REE oxalate precipitates in addition to it is simple, cheap and takes place at room temperature. The reaction can be represented as [37].

$$
2 \mathrm{REE}^{3+}+3 \mathrm{C}_{2} \mathrm{O}_{4}{ }^{2-} \longrightarrow \mathrm{REE}_{2}\left(\mathrm{C}_{2} \mathrm{O}_{4}\right)_{3} \cdot \mathrm{H}_{2} \mathrm{O}_{(\mathrm{s})}
$$

The obtained white precipitate of REE-oxalate product was filtered, washed with distilled water and subsequently dissolved in conc. $\mathrm{HCl}$ followed by precipitation again as REEs oxalates using $10 \%$ oxalic acid. This dry precipitate was ignited at $800^{\circ} \mathrm{C}$ for $2 \mathrm{~h}$ to the corresponding REE-oxides then subjected to EDAX analysis to identify its individual REEs distribution as shown in figure 9. 


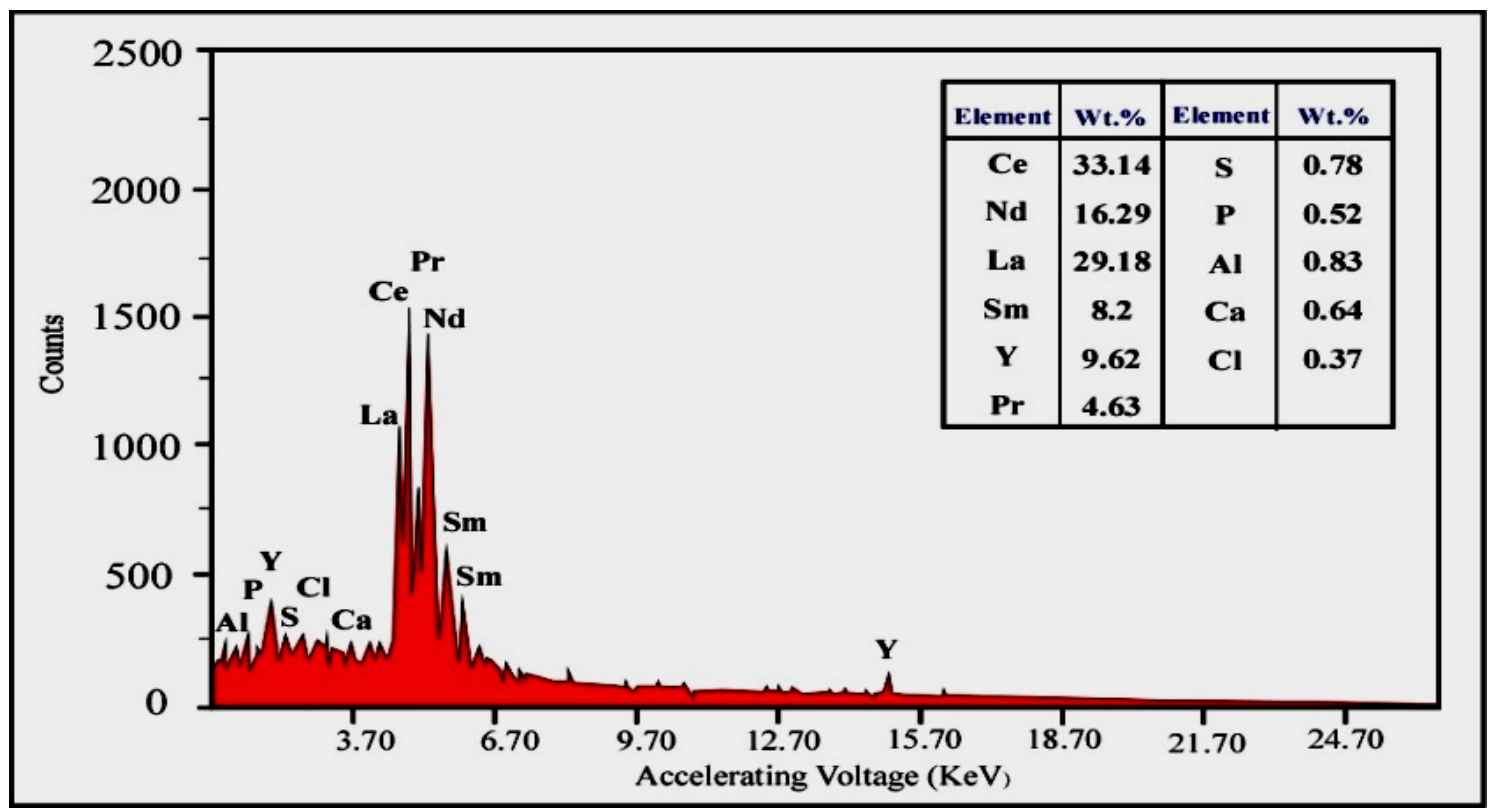

Fig. 9: EDAX analysis of REEs product.

\subsection{Recovery of Copper}

Addition of ammonia solution (28\%) to the uranium effluent liquor and free from REEs adjust the $\mathrm{pH}$ value to 5.5 leading to a precipitation of copper as hydroxide. The obtained precipitate have been calcined resulted in copper oxides then subjected to ESEM -EDAX analysis to confirm the degree of its purity which was found to attain up to about $96.84 \%$ of $\mathrm{Cu}$ as shown in figure 10 .

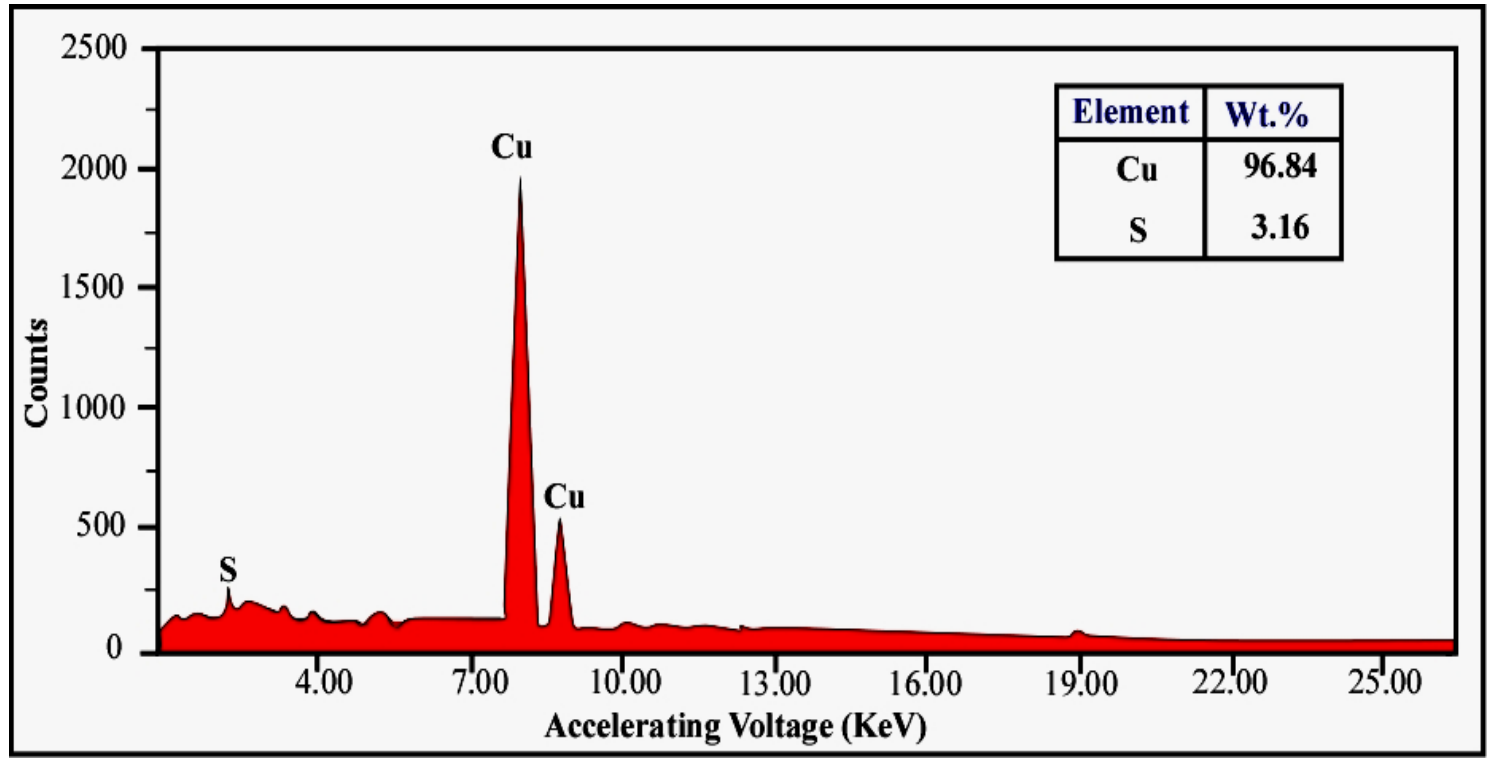

Fig. 10: EDAX analysis of copper product.

\subsection{Si-Gel Precipitation}

In point of economic view, silica gel was obtained as a by-product after removing the valuable elements as $\mathrm{Fe}, \mathrm{U}$, and REEs in addition to $\mathrm{Cu}$ by adjusting the solution $\mathrm{pH}$ 
value to 8.5 via ammonium hydroxide (28\%). The precipitated silica in the form of $\mathrm{SiO}_{2}$ should be washed with dilute $\mathrm{H}_{2} \mathrm{SO}_{4}(1 \%)$ then ignited at $850{ }^{\circ} \mathrm{C}$ for $1 \mathrm{~h}$ and left to cool and then washed. After dryness, the produced $\mathrm{SiO}_{2}$ was recovered with recovery efficiency up to $99 \%$ and identified by means of EDAX analysis as shown in figure 11.

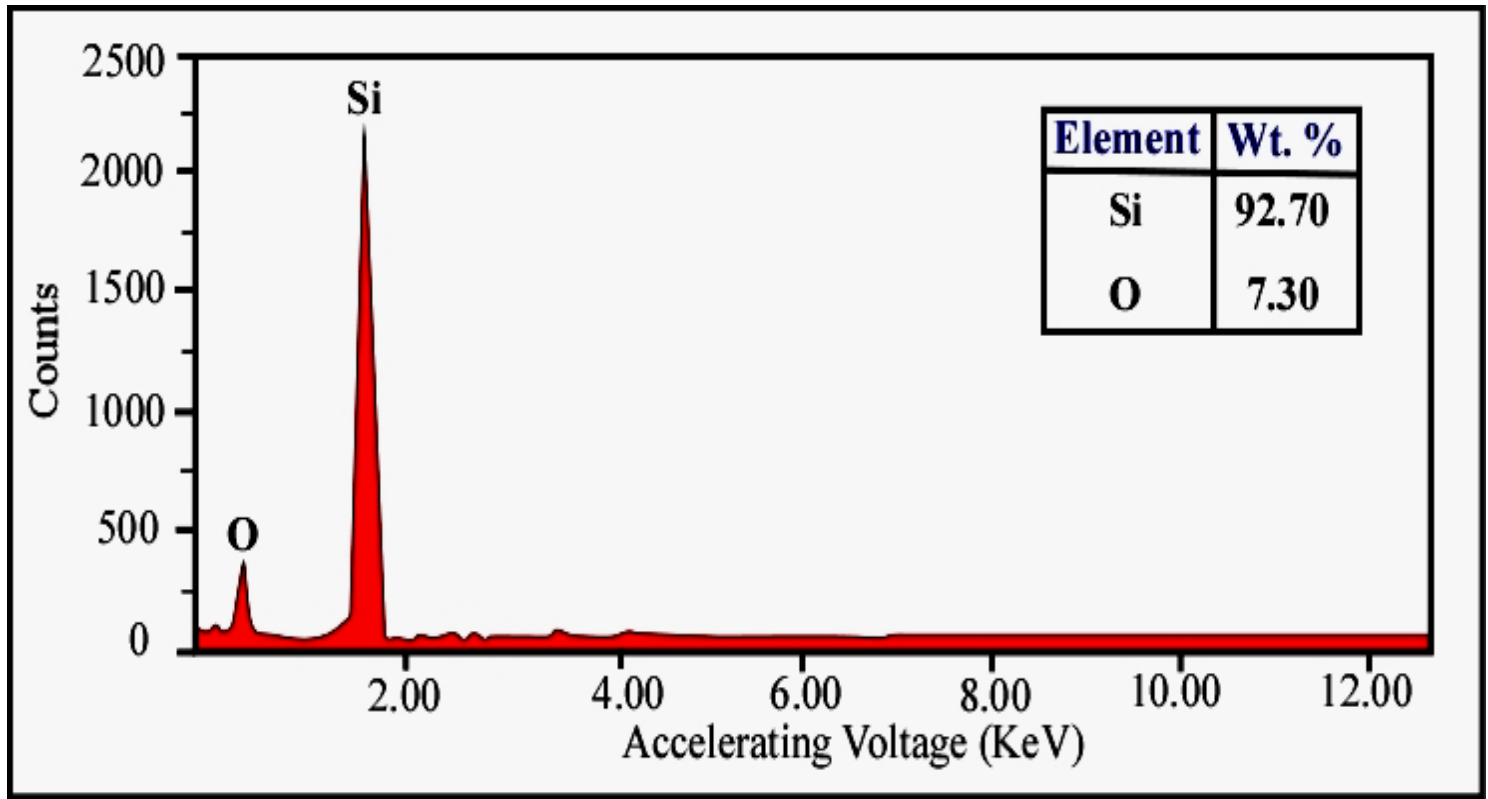

Fig. 11: EDAX analysis of Si-gel product.

\section{Conclusion}

In the present study, the pug leaching technique was applied to U-recovery in addition to some its accompaniment elements from a collected technological sample of ferruginous shale from Wadi Um Hamed of Um Bogma Formation at Abu Thor locality of southwestern Sinai, Egypt. A flow diagram of the proposed technique using the conditions mentioned is included. The diagram shows different subsequent processing stages and the processes governing the U-recovery under the experimental conditions have been identified to be surface chemical reaction model.

\section{REFERENCES}

[1] F. Cardarelli, Materials Handbook, $3^{\text {ed }}$ Edition, Published by Springer International Publishing AG, Switzerland (2018), Chapter 4, pp. 608-616.

[2] G. Lu, A. J. Haes and T. Z. Forbes, Coord. Chem, Rev. 374 (2018) 314-344.

[3] V. Madakkaruppan, A. Pius, T. Sreenivas, N. Giri and C. Sarbajna, J. Hazard. Mater. 313 (2016) 9-17.

[4] G. Z. Koltuniewicz, I. H. Koniecko, C. Cojocaru and E. Chajduk, J. Hazard. Mater 275 (2014) 136-145.

[5] M. B. Revuelta, Mineral Resources from Exploration to Sustainability Assessment, Published by Springer International Publishing AG, Switzerland (2018), Chapter 6, Page 501-509.

[6] Y. Ghorbani, J. P. Franzidis and J. Petersen, Min. Proc. Ext. Met. Rev. 37 (2016) 73119. 
[7] L. Shapiro, Rapid Analysis of Silicate, Carbonate and Phosphate Rocks, Published by Washington, 1975. Page 25-88.

[8] M. Li, C. M. Huang, X. W. Zhang, F. Y. Gaoa, X. Y. Wu, Q. Fang, W. F. Tan and D. Zhang, Hydrometallurgy 180 (2018) 201-209.

[9] E. Kratii, V. Nikonorov and T. Nikitina, Microchem. J. 130 (2017) 198-204.

[10] Y. Mu, A. Saffarzadeh and T. Shimaok, Waste Manage. 59 (2017) 222-228.

[11] C. R. Borra, J. Mermans, B. Blanpain, Y. Pontikes, K. Binnemans and T. V. Gerven, Miner. Eng. 92 (2016) 151-159.

[12] Y. Ohashi, Y. Tanaka, Y. Tsunashima and Y. Ikeda, J. Nucl. Sci. Technol. 54 (2017) 382-390.

[13] K. Z. Elwakeel, A. A. Atia, E. Guibal, Bioresour. Technol. 160 (2014) 107-114.

[14] N. Reynier, R. Lastra, C, Laviolette, J. F. Fiset, N. Bouzoubaa and M. Chapman, Solvent Extr. Ion Exch. 34 (2016) 188-200.

[15] Y. D. Wang, G. Y. Li, D, X. Ding, Z. Y. Zhang, J. Chen, N. Hu and L. Li, J. Radioanal. Nucl. Chem. 304 (2015) 1139-1144.

[16] X. Yin, Y. Zhang, Z. Fang, Z. Xu, W. Zhu and H. He, Cryst. Res. Technol. 45 (2010) 961-964.

[17] S. Makvandia, G. Beaudoina, M. B. M. Clenaghanb and D. Quirtc, J. Geochem. Explor. 183 (2017) 1-21.

[18] H. S. Reynolds, R. Ram, M. I. Powncepy, Y. Yang, M. Chen, J. Tardio, L. Jones and S. K. Bhargava, Trans. Nonferrous Met. Soc. China 28 (2018) 2135-2142.

[19] W. Dong, T. K. Tokunaga, J. A. Davis and J. Wan, Environ. Sci. Technol. 46 (2012) 1565-1571.

[20] B. J. Youlton and J. A. Kinnaird, Gangue-reagent interactions during acid leaching of uranium.Miner. Eng. 52 (2013) 62-73.

[21] D. Rinsant, E. Andreiadis, M. Carboni and D. Meyer, Mater. Lett. 253 (2019) 285288.

[22] S. K. Bhargava, R. Ram, M. Pownceby, S. Grocott, B. Ring, J. Tardio and L. Jones, Hydrometallurgy 151 (2015) 10-24.

[23] M. Roshani and K. Mirjalili, Hydrometallurgy 98 (2009) 304-307.

[24] Y. F. Xiao, Z. Y. Feng, G. H. Hu, L. Huang, X. W. Huang, Y. Y. Chen and M. L. Li, Rare Met. 34 (2015) 357-365.

[25] Li, X.; Xing, P.; Du, X.; Gao S. and Chen, C.: "Ultrason.”, Sonochem. 38, pp. 84-91, (2017).

[26] S. A. Hosseini, S. Raygan, A. Rezaei and A. Jafari, J. Environ. Chem. Eng 5 (2017) 3922-3929.

[27] A. C. Niam, Y. F. Wang, S. W. Chen and S. J. You, J. the Taiwan Institute of Chemical Engineers 97 (2019) 137-145.

[28] S. Janyasuthiwong, R. Ugas, E. R Rene, C. Alessandra, G. Esposito and P. N. Lens, J Chem. Technol. Biotechnol. 91 (2016) 2038-2046.

[29] A. Azimi, A. Azari, M. Rezakazemi and M. Ansarpour, Chem. Bio. Eng. Rev. 4 (2017) 37-59.

[30] H. Kokes, M. H. Morcali and E. Acma, Eng. Sci. Technol, an Int. J. 17 (2014) 39-44.

[31] R. Zarrouguia, R. Mdimagh and N. Raouafi, J. Hazard. Mater. 342 (2018) 464-476.

[32] J. T. M. Amphlett, M. D. Ogden, R. I. Fostera, N. Syna, K. Soldenhoff and C. A. Sharrad, Chem. Eng. J. 334 (2018) 1361-1370.

[33] H. Tavakoli, H. Sepehrian, F. Semnani and M. Samadfam, Ann. Nucl. Energy 54 (2013) 149-153. 
[34] S. K. Gupta, A. R. Dhobale, M. Kumar, S. V. Godbole and V. Natarajan, J. Mol. Struct. 1084 (2015) 89-94.

[35] S. M. Mousavi, H. Tavakoli, M. Samadfam, F. Semnani, Z. Asadi and H. Sepehrian, Res. Chem. Intermed. 39 (2013) 951-959.

[36] T. V. Lien, T. T. Dinh and N. T. K. Dung, Hydrometallurgy 191 (2020) 105164.

[37] D. Beltrami, G. J. P. Deblonde, S. Bélair and V. Weigel, Hydrometallurgy 157 (2015) 356-362.

[38] P. Wang, E. Hu, Q. Wang, Z. Lei, H. Wang, Y. Zhang, W. Hou and R. Zhang, J. Radioanal. Nucl. Chem. 322 (2019) 597-604.

[39] N. Habbache, N. Alane, S. Djerad, L. Tifouti, Chem. Eng. J. 152 (2009) 503-508.

[40] F. Kocan and U. Hicsonmez, Int. J. Min. Met. Mater. 26 (2019) 11-20.

[41] Y. Tang, T. Shen and Z. Meng, Environ. Geochem. Health. 41 (2019) 2491-2503.

[42] R. Du, X. Zhang, M. Li, X. Wu, Y. Liu, T. Jiang, C. Chen and Y. Peng, J. Radioanal. Nucl. Chem. 322 (2019) 839-846.

[43] D. Wu, S. Wen and J. Deng, New J. Chem., 39 (2015) 1922-1929.

[44] L. j. Liu, H. Du, Y. Zhang, S. 1. Zheng and Y. Zhang, Trans. Nonferrous Met. Soc. China 27 (2017) 891-900.

[45] B. Mojtahedi, S. Rasouli and H. Yoozbashizadeh, Trans. Indian Inst. Met. 73 (2020) 975-987.

[46] J. Maa, S. Zhang, R. Lv, W. Wang, Y. Qin and C. Wang, Sep. Sci. Technol. 52 (2017) 132-141.

[47] W. J. rui and Z. Jie, Russian J. Applied Chem. 89 (2016) 1196-1205.

[48] M. Li, B. Liu, S. Zheng, S. Wang, H. Du, D. B. Dreisinger and Y. Zhang, J. Clean. Prod. 149 (2017) 206-217.

[49] A. A. Baba, M. K. Ghosh, S. R. Pradhan, D. S. Rao, A. Baral and F. A. Adekola, Trans. Nonferrous Met. Soc. China 24 (2014) 1587-1595. 